\section{Tidlig hjemreise kan føre til dehydrering}

\author{
Kort liggetid på barselavdelingen synes å medføre flere reinnleggelser av dehydrerte nyfødte i sykehus.
}

den vestlige verden i dag blir liggetiden i barselavdelingene stadig kortere. I USA, der mye relateres til biler, er uttrykket «drivethrough-deliveries» blitt brukt. De siste tiårene har man også sett en reduksjon av liggetiden på norske barselavdelinger, mor og barn reiser hjem etter bare to, tre dager (1). Forskning viser at kortere liggetid i barselavdeling kan være en risikofaktor for utvikling av alvorlig dehydrering blant norske nyfødte (2). Forskerne mener her at man ser økt antall innleggelser av nyfødte med alvorlig dehydrering på grunn av sviktende amming. Det er ikke uvanlig at nyfødte går ned opptil 10 prosent av fødselsvekten, før de snur i vekt noen dager etter fødsel.

\section{Hovedbudskap}

De siste tiårene har man sett en reduksjon av liggetiden på norske barselavdelinger, mor og barn reiser ofte hjem etter to, tre dager. Enkelte steder er det satt i gang prosjekter hvor mor og barn skal reise hjem etter seks timer. Den kortere liggetiden er ikke kompensert for med andre tilbud. Studier viser økt innleggelse av nyfødte med dehydrering som følge av sviktende amming.

\section{Nøkkelord}

Les mer og finn litteraturhenvisninger på våre nettsider. ) Nyfødt | Dehydrering / Amming
Mesteparten av denne nedgangen skyldes tap av væske og har sammenheng med at melkeproduksjonen ikke har kommet ordentlig i gang. I de tilfeller der barna ikke får nok melk eller væsketapet er patologisk, kan vekttapet bli enda større. Gjennomsnittlig vekttap i nyfødtperioden rapporteres å ligge rundt $6-7$ prosent. Laveste vekt når de som regel ved to til tre dagers alder, og brysternærte barn innhenter i gjennomsnitt fødselsvekten etter åtte til ni dager (3). I denne artikkelen vil vi se nærmere på hvordan helsesøster kan bidra til å forebygge dehydrering hos nyfødte etter at mor og barn er skrevet ut fra barsel. Hensikten er også å belyse farene ved at mor og barn så raskt blir sendt hjem fra barselavdelingen.

\section{Problemstilling}

Dehydrering hos spedbarn er en potensielt livstruende tilstand, med fare for tromboser, cerebrale blødninger og hypovolemisk sjokk. Nyfødte som får utilstrekkelig væsketilførsel, har økt risiko for hyperton dehydrering med hypernatremi (4). Det vil si at barnet har redusert evne til å konsentrere urin med påfølgende stort renalt vanntap, i tillegg til vanntap gjennom hud og lunger. Elektrolyttforrådene vil være bevart, og dermed vil konsentrasjonen av natrium være stor. Risikoen for hyperton dehydrering stiger med graden av det relative vekttapet, og hypernatremi ble i studiene observert først etter fjerde levedøgn (5).

I dag reiser mor i gjennomsnitt hjem fra bar- selavdelingen før eller akkurat idet ammeprosessen er kommet i gang. Samtidig viser studier $ø \mathrm{kt}$ innleggelse av nyfødte med dehydrering som følge av sviktende amming. Lege og forsker Malin Eberhard-Gran ved Folkehelseinstituttet spør om helsetjenesten er organisert slik at dagens barselkvinner, og deriblant de nyfødte barna, blir tatt godt vare på når de drar tidlig hjem (1). For førstegangsfødende er det vanlig at ammingen kommer i gang på tredje eller fjerde dag. Det betyr at mor reiser hjem før ammeprosessen er kommet ordentlig i gang. Det er stor variasjon både i innhold og kvalitet på barselomsorgen i Norge, og på flere sykehus planlegger man at nyfødte og barselkvinner reiser hjem innen 24 timer (6). Medisinsk kunnskap og erfaring tilsier at det ikke er nødvendig med et langt sykeleie etter en fødsel, men den reduserte liggetiden vi opplever nå har selvfølgelig også sammenheng med økonomi i helsetjenesten.

Artikkelen er basert på en litteraturstudie, og problemstillingen er: «Hvordan kan helsesøster bidra til å forebygge dehydrering hos nyfødte?» Vi vil først vise til relevante resultater av forskning og rapporter som bidrar til å belyse problemstillingen, deretter diskutere resultatene i lys av aktuelle funn i offentlige dokumenter.

\section{Resultater}

Det er begrenset med forskning på barselomsorg. Marit Heiberg refererer til en systematisk oversikt fra 2002 av studier med til 

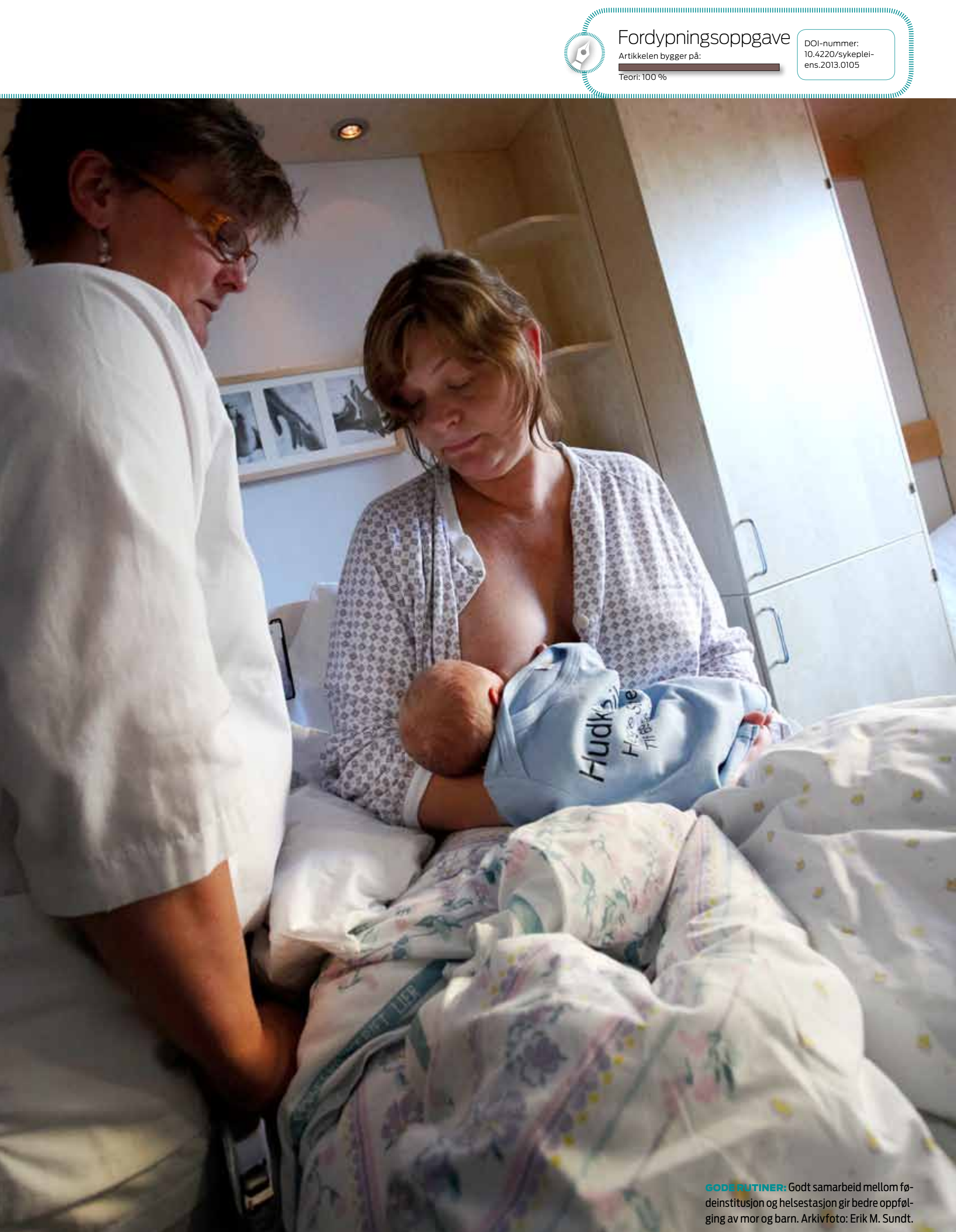
sammen 3600 kvinner, der man så på tidlig hjemreises innvirkning på kvinner med et normalt svangerskap og som fødte til termin (1). På grunn av studienes metodiske begrensninger kunne man ikke si noe bastant om fordeler eller ulemper ved tidlig hjemreise fra sykehuset. Altså fantes det i 2002 for lite og for dårlig forskning på emnet. Dette kan tyde på at kortere liggetid ikke bygger på kunnskap, men er innført som et økonomisk incitament. Mangel på forskning kan føre til at omsorgen i større grad blir styrt av sedvane enn av forskningsbasert kunnskap.

\section{Reinnlagt med vekttap}

En studie som er gjort ved barneklinikken ved Haukeland universitetssykehus (2), konkluderer med at kortere liggetid i barselperioden kan

\section{«For førstegangsfødende er det vanlig at ammingen kommer i gang på tredje eller fjerde dag.॥}

være en risikofaktor for utvikling av alvorlig dehydrering hos nyfødte. Forskerne har gjennomgått journaler over alle fullbårne barn under tre uker som ble reinnlagt fra hjemmet med vekttap på 12 prosent av fødselsvekten. De ble sammenliknet med kontrollbarn fra barselavdelingene. Av barn født i perioden 2002-2008, viste det seg at 38 barn (1 prosent) ble identifisert, av totalt 37 321. Det er en signifikant økning av antall innleggelser grunnet dehydrering per år i denne tiden. Gjennomsnittlig liggetid i barselavdelingene gikk ned fra 3,5 døgn til 2,7 døgn i samme tidsrom. Gjennomsnittsalder ved reinnleggelse var seks døgn, og vektnedgangen var i gjennomsnitt 15 prosent av fødselsvekten.

\section{Lite væskeinntak}

Den kvalitative studien beskriver en pike som ble lagt inn på sykehus med et betydelig vekttap som krevde behandling og nøye overvåkning (5). Mor fortalte at barnet alltid virket sultent og at det lå mye ved brystet. Barnet virket kvikt og hadde ingen andre åpenbare tegn på dehydrering, men det var usikkert hvor mye urin det hadde kvittert i bleiene. Blodprøver var forenlig med hyperton dehydrering med hypernatremi og mest sannsynlig kom dette av for lite væskeinntak. Mor hadde for lite melk og det viste seg at hun hadde tilegnet seg en uhensiktsmessig ammeteknikk som gjorde at det var vanskelig for barnet å få nok melk.

\section{Hjemmebesøk}

I en studie av Michel Boulvain et al. observerte man også en tendens til flere reinnleggelser av barn i en hjemmeomsorgsgruppe i løpet av de seks første månedene etter fødsel (7). Denne studien er en sveitsisk randomisert kontrollert studie, basert på 459 kvinner med lavrisikosvangerskap i tiden fra november 1998 til oktober 2000. 228 kvinner reiste hjem etter 24-48 timer og ble fulgt opp av jordmor tett i etterkant, mens 231 kvinner lå på sykehuset i fire til fem dager etter fødsel og mottok tradisjonell barselomsorg. Det ble konkludert med at tidlig hjemreise og jordmorbesøk i hjemmet etter fødsel kan være et akseptabelt alternativ til lengre opphold på sykehus.

I en undersøkelse fra et dansk sykehus i 2005 fant de at 4,9 prosent av de nyfødte ble reinnlagt med et vekttap $>10$ prosent, hvorav en fjerdedel med hypernatremisk dehydrering (8). Undersøkelsen viste at nyfødte barn ofte skrives ut før de har en tilfredsstillende ernæringstilstand. Forfatterne anbefaler regelmessig veiing, helst fjerde til femte dag, da dette vil kunne avsløre fallende vekt og indisere behandling før tilstanden blir livstruende. De konkluderer med at hjemmebesøk bør skje innen sjuende dag.

\section{Ammeveiledning}

Tidlig hjemreise etter fødsel kan gi nye utfordringer for familien. Esther Hjälmhult har gjort en omfattende undersøkelse av betydningen av helsesøsters hjemmebesøk (9). I Bergen så de at da helsesøster kom hjem til barselkvinnen ble det færre ekstrakonsultasjoner på helsestasjonen i etterkant. Antall utførte hjemmebesøk er redusert de siste årene. Samtidig som mor og barn utskrives tidligere fra fødeinstitusjonen viser det seg også at ammefrekvensen har sunket. Hennes forskning viser også at mødre som hadde fått hjemmebesøk, oppga at de fikk bedre ammeveiledning og var tryggere i eget miljø. Hvis mor opplever større trygghet i eget miljø, vil hun muligens også være mer fornøyd med ammeveiledningen. Dette vil igjen ha betydning for barnets vekst og utvikling.

\section{Særlig sårbare}

I rapport fra tilsyn med barselomsorgen (6) viser de faktiske tallene at det er liten forskjell på liggetiden for førstegangsfødende og flergangsfødende. Fødeinstitusjonene har selv myndighet til å avgjøre når barselkvinnen og barnet er utskrivningsklare, og det viser seg at to-tre liggedøgn blir praktisert både ved de fødeinstitusjonene som tilbyr hjelp ved barselpoliklinikk og de som ikke gjør det. Blant dem som ble skrevet ut i løpet av ett til tre døgn var det også kvinner som ble omfattet av begrepet «særlige sårbare grupper» som enslige, førstegangsfødende, tenåringsmødre, barn med lav fødselsvekt og så videre. I tillegg viser det seg at liggetiden etter kompliserte fødsler bare i få tilfeller er lengre enn fødsler uten komplikasjoner. Flere helseforetak hevder at barselkvinnene selv ønsker å reise tidlig hjem, mens helsesøstre viser til at barselkvinnene selv rapporterer om høyt tempo og trangt om plassen ved barselavdelingene og at de av den grunn ønsker å reise hjem etter to-tre døgn.

Stortingsproporsjon 91 slår fast at den pågående utviklingen med tidligere utskrivning fra fødeinstitusjonene vil stille økte krav til den lokale barselomsorgen (10). Det å være frisk barselkvinne med en normal fødsel er kanskje ikke ensbetydende med at hun ikke trenger oppfølging når hun kommer hjem.

\section{Behovsstyrt omsorg}

Bjørn Backe, overlege ved Kvinneklinikken på St. Olavs Hospital, spør om helsetjenesten er god nok til å differensiere mellom de som ønsker og kan reise hjem tidlig og de som faktisk både bør og skal ha ett eller flere døgn ekstra på barselavdelingen (11). Han mener det er på tide å flytte diskusjonen om barselperioden fra lengden av barseloppholdet etter normal fødsel, til behovet for oppfølging og støtte etter fødsel. Et eksempel på dette er at omtrent 65 prosent av alle barselkvinner i Fjell kommune i Bergen nå får barselomsorg på kommunalt nivå (12). Prosjektet JordmorHeim tilbyr oppfølging av barselkvinner og nyfødte som er skrevet ut før Føllings prøve er tatt. Oppfølgingstiden er primært den første uka etter fødsel. JordmorHeim har tett samarbeid med helsesøstre i Fjell som overtar oppfølgingen etter den første uken. Den nye familien slipper da å reise tilbake til sykehuset for barselpoliklinikk og Føllings prøve.

Ifølge norske forskrifter skal hjemmebesøk tilbys før det er gått to uker (13). Norske helsesøstre har gjennom årtier tilbudt hjemmebesøk til foreldre med nyfødte barn. Helsetilsynet har i det siste fått tilbakemeldinger fra helsesøstre i kommunene om svikt i helsetilbudet til nyfødte og deres familier. Helsestasjonene registrerer en $ø$ kning av foreldre som er usikre i forhold til 
det nyfødte barnet, og det handler hovedsakelig om ammeproblemer og spørsmål om barnet får i seg nok næring (6).

\section{Rutiner og samarbeid}

Gode rutiner og samarbeid mellom fødeinstitusjon og helsestasjon er viktig for å sikre effektiv oversendelse av fødselsmeldinger og mulighet for tidlig hjemmebesøk. Tilsyn med barselomsorgen viser at fødselsmeldingen ofte kommer for sent til helsestasjonen, det vil si først etter at familien selv har tatt kontakt for å få hjelp (6). Det kan i praksis bety at fra mor reiser hjem til helsesøster kommer på hjemmebesøk, kan det gå mer enn de to ukene man anbefaler i veilederen (3). Nødvendig oppfølging av mor og barn de første dagene må skje i samarbeid mellom spesialist- og kommunehelsetjenesten, og helsesøster bør gi alle et tilbud om hjemmebesøk i løpet av den første uken etter fødsel. Helsesøster er hovedaktør når det gjelder å følge opp det nyfødte barnet ved helsestasjonen. Det er selvfølgelig betenkelig at tilsyn med barselomsorgen viser at bare 57 av 98 nybakte familier hadde fått hjemmebesøk innen to uker etter fødsel, 41 av 98 familier hadde ikke fătt hjemmebesøk i det hele tatt. Av disse var det 15 førstegangsfødende (6).

Stortingsmelding nr. 12 sier at helsestasjonene skal kunne motta elektronisk melding om fødsel raskt etter at barnet er født, men per i dag vet vi at et slikt elektronisk meldesystem ikke fungerer overalt (14). For å sikre at helsestasjonen får tidlig beskjed om fødsel kan helsesøster ringe barselavdelingen selv, men dette ikke er et godt nok system.

\section{Veiing viktig}

Forskningen viser at når friske kvinner med normale fødsler ønsker å reise tidlig hjem fra barselavdelingen, er det fullt forsvarlig så lenge det er en utbygd helsetjeneste i kommunen til å ta imot mor og barn (1). I Stortingsmelding 12 står det at svangerskap og fødsel er en normal livshendelse og ikke en sykdom. Dette er samtidig en svært sentral livshendelse hvor det $\mathrm{i}$ enkelte situasjoner kan stå om liv og død, både for mor og barn. Tjoras undersøkelse fra Bergen viser at insidensen av reinnleggelser av dehydrerte barn har økt i takt med kortere liggetid på barsel (2). Tjora mener at veiing er den eneste sikre måten å avdekke stort vekttap på. Han mener at oppførsel hos barnet, gulsott, urin- og avføringsfrekvens ikke er sensitivt nok til å fange opp risikobarn. Nyfødte kan være be- tydelig dehydrerte uten å være klinisk preget av dette. Tidlig veiing etter hjemreise kan derfor være nødvendig for å fange opp risikobarn og forhindre alvorlig dehydrering (5). Alf Meberg ved barnesenteret, Sykehuset i Vestfold, sier i en kommentar i Tidsskrift for Den norske legeforening (15) at veiing i første eller andre leveuke er nødvendig for å oppdage at ernæringen av barnet er utilstrekkelig. Han mener at veiing er en enkel prosedyre å gjennomføre som gir gode resultater på å forebygge dehydrering.

Gorm Greisen (16) referer til en dansk forsker, Ester Garne, som foreslår en rutinemessig veiing i slutten av første leveuke. Det er enkelt og i tråd med de nye norske anbefalinger om veiing og måling i helsestasjonstjenesten. Hun mener derimot at et alternativ til veiing kan være bedre informasjon om kliniske tegn på dehydrering, som for eksempel tørre bleier.

Helsesøstre bør ta viktigheten av veiing på alvor, og nye anbefalinger sier nå at spedbarn bør veies innen sju til ti dager for å kartlegge ammesituasjonen (3). Ved å komme tidlig på hjemmebesøk og veie barna ser man om ammingen er godt etablert og om barnet legger på seg tilfredsstillende. Ifølge norske forskrifter skal hjemmebesøk skje innen to uker, men siden flere sykehus nå planlegger å sende hjem mor og barn innen 24 timer etter fødsel, bør hjemmebesøket finne sted innen sjuende dag. Det er alvorlig at spedbarn i ytterste konsekvens kan bli innlagt med dehydrering på grunn av for lite melk fra mor, når undersøkelser viser at den hyppigste årsak til for lite melk er feil ammeteknikk.

Mangelfull vektoppgang hos brysternærte barn bør følges opp med kartlegging av ammesituasjonen, etterfulgt av adekvate råd og evaluering av amming og vektutvikling til situasjonen er avklart (3).

Regjeringen anbefaler at det på grunn av tidlig hjemreise må bygges opp kompetanse ved helsestasjonene for å utføre nødvendige medisinske undersøkelser av nyfødte (14). Det må også være nok kapasitet til å følge utviklingen hos nyfødte, blant annet for å sikre at ammingen kommer i gang og at vektøkningen har startet.

\section{Konklusjon}

Kort liggetid på barselavdelingen kan være en risikofaktor da det viser seg at flere nyfødte er blitt reinnlagt på sykehus på grunn av alvorlig dehydrering, hvor sviktende amming er en av hovedårsakene. Både norske og internasjonale studier antyder at tidlig hjemreise etter fødsel ikke innebærer negative konsekvenser for det nyfødte barnet, så sant det er etablert en kompetent tjeneste som er lett tilgjengelig og som møter barselkvinnens og det nyfødte barnets behov (6). Helsestasjonen må sikre at alle får

\section{«Den hyppigste årsak til for lite melk er feil ammeteknikk.»}

tilbud om tidlig hjemmebesøk da gode veie- og oppfølgingsrutiner kan forebygge mangelfull vektoppgang og dehydrering hos nyfødte. Helsesøster bør veie nyfødte helst etter fjerde-femte dag og innen sju til ti dager for å kartlegge ammesituasjonen. Dehydrering kan forebygges ved at man kommer tidlig på hjemmebesøk, for å observere og veie de nyfødte samt sikre god ammeveiledning. IIII

\section{REFERANSER}

Heiberg M. Barselomsorg giennom tidene. Tidsskrift for jordmødre, tema 2008

2. Tjora E, Karlsen LC, Moster D, Markestad T. Early severe weightloss in newborns after discharge from regular nurseries. Acta Pædiatr 2010; May; $99(5)$ :

3. Nasjonale faglige retningslinjer for veiing og måling i helsestasjons- og skolehelsetjenesten. 2011. Helsedirektoratet.

4. Jacobsen D, Ingvaldsen B, Kjeldsen SE, Lund K, Solheim K. Sykdomslære: indremedisin, kirurgi og anestesi. Opplag 6. Oslo: Gyldendal akademisk, 2009

5. Tjora E, Reigstad H. En seks dager gammel pike med vektnedgang. Tidsskr Nor Legeforen 2009; 129: 868-9.

6. Korleis tek fødeinstitusjonane og kommunene vare på behova til barselkvinna og det nyfødde barnet i barseltida? Rapport frå tilsyn med barselomsorga. Rapport fra helsetilsynet 3/2011. Helsetilsynet.

7. Boulvain M et al. Home - based versus hospital-based postnatal care: a randomized trial. RCOG 2004 BJOG: an International Journal og Obstetrics and Gynaecology 2004; 111: 807-13.

8. Reilev M, Børch K, Pryds OA. Hypernatriæmisk dehydrering hos nyfødtehvorfor stigende incidens? Ugeskrift læger 2007; 169: 1227-31.

9. Hiälmhult E. Skal helsesøster tilby hiemmebesøk til alle foreldre med nyfødt barn? Sykepleien Forskning 2009; 4(1): 18-26.

0. Lov om kommunale helse- og omsorgstjenester m.m. (helse- og omsorgstjenesteloven) Prop. 91 L. (2010-2011) Helse- og omsorgsdepartementet.

1. Backe B. Fødsel, barsel og ritualer. Tidsskr Nor Legeforen 2003; 123: 3510. . Jordmorheim i Fjell kommune: Rapport http://www2.fjell.kommune.no/ Tjenester/Tenestebeskrivelser/JordmorHeim-i-Fjell/

13. Forskrift om kommunenes helsefremmende og forebyggende arbeid $i$ helsestasjons-og skolehelsetjenesten $\$ 2-3$. (2003) Helse- og omsorgsdepartementet. Lovdata.

14. En gledelig begivenhet-om en sammenhengende svangerskaps-fødsels-og barselomsorg. St.meld.nr 12 (2008-2009) Helse- og omsorgsdepartementet. Meberg A. Veiing er viktig i barseltiden. Tidsskr Nor Legeforen 2009;129:869-70.

16. Greisen $G$. Veining af nyfødte-for en sikkerhets skyld? Ugeskrift læger $164 / 48.2002$

Fagartikler kan sendes til torhild.apall@sykepleien.no 